pp. $725-738$

\title{
Problems of Legal Enforcement of Provisions on Economic Fraud Under National and Foreign Criminal Legislation and Assessment of the Related Risks
}

\author{
Submitted 06/06/20, 1st revision 20/07/20, 2nd revision 15/08/20, accepted 15/09/20 \\ Kobleva M.M. ${ }^{1}$, Osadchaya N.G. ${ }^{2}$, Seregina E.V. ${ }^{3}$, Fomenko I.V. ${ }^{4}$, \\ Kazarinov I.A. ${ }^{5}$, Pateeva D.R. ${ }^{6}$
}

Abstract:

Purpose: The objective of this article is to analyze the problems of criminal liability for various kinds of economic fraud in criminal law.

Design/Methodology/Approach: In the course of the study, the authors have analyzed the provisions of foreign and national legislation governing criminal liability for fraud. An assessment of risks related to various kinds of economic fraud has been performed. Analysis of crime rate for January-June 2020 shows that in the Russian Federation nearly 26 thousands of such criminal acts are committed each month on average, with the number of committed acts of economic fraud steadily increasing.

Findings: As a result, the authors have concluded on the need to improve the provisions of national criminal legislation on economic fraud taking into account the positive experience of foreign criminal law, with assessment of the risks related to various kinds of economic fraud for the purpose of counteracting such criminal acts.

Practical Implications: Study of the comments concerning imperfection of provisions on economic fraud represented in legal literature makes it evident that there is a long-standing need for their reforming. Certain considerations on improvement of provisions of criminal legislation on various kinds of economic fraud are set forth, and also a method for calculating the risks related thereto is proposed.

Originality/Value: With an integrated approach to study of the problems of criminal liability for economic fraud, an understanding of the complexities of qualifying the given crime is elaborated, as well as a mechanism for specifying an adequate and proportionate punishment for its commission.

\footnotetext{
${ }^{1}$ Candidate of law, associate professor, Russian State University of Justice, Rostov-on-Don, Russian Federation, kobleva_maria@mail.ru

${ }^{2}$ Candidate of law, associate professor, Russian State University of Justice, Rostov-on-Don, Russian Federation, natik3sol@mail.ru

${ }^{3}$ Candidate of law, associate professor, Russian State University of Justice, Rostov-on-Don, Russian Federation, seregina51@mail.ru

${ }^{4}$ Candidate of law, associate professor, Russian State University of Justice, Rostov-on-Don, Russian Federation, 777_74@mail.ru

${ }^{5}$ Vice editor-in-chief, journal "Science and Education: Economy, Entrepreneurship, Law and Management”, Russian Federation, spqn95@gmail.com

${ }^{6}$ Part-time post-graduate student, Rostov State University of Economics (Russian Institute of National Economy), Rostov-on-Don, Russian Federation, pateeva_di@mail.ru
} 
Keywords: Economic fraud, fraudulent behavior, breach of trust, criminal liability, criminal punishment, risks related to fraud, counteraction.

JEL codes: $K 14, K 11, K 42$.

Paper type : Research article.

\section{Introduction}

In the modern world, protection of property relations is of tremendous value. In all periods of the historical development of society, the interests of owners have been strictly protected by the provisions of law, while violation of property rights always entailed the most severe measures of legal liability.

Among the entirety of crimes against property, economic fraud holds a prominent place due to that it is committed in a special way whereby the owner can lose his property under the influence of deception, delusion or excessive credulity. The statistics of these crimes is steadily growing from year to year, and in the past few months, in the context of the pandemic announced by the World Health Organization, a sharp quantitative jump was detected of the types of economic fraud committed both in the Russian Federation and in other countries.

When deciding on the prosecution of persons committing various types of economic fraud, the law enforcement officers often have difficulties in qualification of fraudulent actions, interpretation of certain provisions of criminal law, as well as in diversification of certain special types of economic fraud from adjacent crimes and from civil law relations.

All these points require a profound study of the provisions of national and foreign criminal legislation on fraud, as well as that of the judicial and investigative practice in the given category of cases and an assessment of the possible risks caused by fraudulent actions. As a result of such an integrated approach to study of the problems of criminal liability for economic fraud, an appreciation of complexities of qualifying this crime, as well as of the mechanism for determining an adequate and proportionate punishment for its commission, should be elaborated.

\section{Provisions of Foreign Criminal Legislation Governing Criminal Liability for Economic Fraud}

At the modern stage of development of the world community, economic crimes are evolving with emergence of their new types and methods of committing crimes. These circumstances cannot but cause anxiety. Due to the trends observed in the criminal world, the issue of effective counteracting them is becoming more acute and challenging (Bissengal et al., 2017). 
While developing measures of criminal legal counteraction to various kinds of crimes in the economic domain, the domestic legislators have widely involved the positive experience of foreign countries in the regulation of various crimes, including economic fraud. It is doubtless that the legislative ways of solving various kinds of problems employed by foreign countries are not always practically applicable in our society, as well as the foreign provisions are not always compatible in the optimal way with the Russian realities due to different factors. Nevertheless, the criminal legislation of many present day states, like also the Criminal Code of the Russian Federation, envisages economic fraud within its provisions as one of the types of crimes against property.

The definitions given in criminal laws of foreign states are largely similar, while also having certain traits corresponding to the social, economic, legal and other features of a specific state. We will consider the foreign experience of criminal counteracting fraud through the examples of several states.

In Germany, compliant to the Criminal Code adopted on May 15, 1871, the system of fraudulent property encroachments includes the following elements of crime:

- fraud, which is misleading or maintaining of delusion with selfish intent, resulting in property damage;

- computer fraud, which influences the data processing with selfish intent, resulting in property damage;

- fraud to obtain subsidies, suggesting one of four alternative acts: reporting false information to the subsidizing authority; use of subsidy contrary to the restriction; failure to inform the subsidizing authority of significant facts; use of evidence obtained on the basis of false information;

- capital investment fraud, which is giving false information to a large circle of persons or omitting disadvantageous facts related to the circumstances significant for making a decision to purchase equities or shares;

- abuse related to insurance, which is damage, destruction or concealment of the insured item in order to obtain insurance payout;

- receiving services in a manipulative way. This provision is applied once the actions of the perpetrator should not be qualified under more severe punishment according to other provisions of the Criminal Code of the FRG;

- fraud aimed at obtaining a loan, which is reporting false information on economic situation, profitable for the person receiving the loan and significant for making a decision on granting a loan (Shabalin, 2014).

Under the law of Germany, deception is the basis of all fraudulent crimes. In some cases, deception and fraud are used synonimically. In our opinion, the criminal law of Germany is the one closest by content to the Russian Criminal Code in specifying the types of fraud, whilst the absense of legal interpretation of terms used by the German legislation in determination of such concepts as "fraud", "deception", "malpractice", "injury", is probable to cause difficulties in qualification of similar acts. 
The criminal legislation of Austria distinguishes between the liability for qualified and highly qualified fraud. In particular, the qualifying indicators are:

- use of a counterfeit document;

- use of a counterfeit or someone else's cashless means of payment;

- causing damage over 3 thousand euro;

- use of incorrect or falsified data.

If these indicators are present, the person should be punished with imprisonment for up to three years.

As a highly dangerous indicator, damage in the amount of more than 50 thousand euro is recognized, in the presence whereof the perpetrator should be punished with imprisonment for a term of 1 to 10 years.

The Criminal Code of Austria, adopted on January 29, 1974, which took effect on January 1, 1975, and has been subsequently repeatedly amended and supplemented, separately regulates the cases when fraud is considered a trade, as well as the case of "professional fraud". A person who committed fraud as a trade should be punished with imprisonment for a term of six months to five years. Therewith, a person who committed fraud in order to obtain permanent income through repeatedly deception should be punished with imprisonment for a term of 1 year to 10 years.

Beside that, in the Austrian criminal law the conditions are envisaged, under which social danger of fraud is decreased once it is committed under enforced circumstances. For example, in some cases, the guilty in committing fraud, who has caused insufficient damage out of necessity should be sentenced to imprisonment for 1 month or a fine of 60 daily fees.

Thus, in the Criminal Code of Austria, differentiation of criminal liability for fraudulent actions is traced. Besides, the Criminal Code of this country mentions specific cases of release of liability for committing fraud.

In England the liability for fraud is provided for by the Law on fraud of 2006. In this law the following is specified:

1) fraud by misleading;

2) fraud with the use of official position;

3) fraud by concealing information of important legal significance.

Maximum punishment for this type of crime is 10 years of imprisonment.

Under the English law, fraud by misleading is a deliberate misleading of affected person in order to obtain profit for one's self or for the sake of other person, or with causing damage to other person, or making a threat of causing such damage. 
Fraud by concealing information of important legal significance is malevolent concealing of information, which a person was obligated to provide.

To qualify an act as fraud through misuse of official position, the following items shall be present:

1) crime is committed by a person having certain official powers and obligated to protect finance interests of other person or not to act against them;

2) person commits an act (action or inaction) malevolently while misusing its position;

3) person has a fraudulent intent (Chetyrin, 2009).

Besides the Law on fraud, other regulatory legal provisions describe special types of fraud, for example:

- forgery and counterfeiting (Counterfeiting and Forgery Act 1981 and Forgery Act 1913);

- malevolent preservation of an illegally obtained loan;

- fraud in the rental of social housing.

In the USA there is no unified criminal legal system which is determined by specifics of American federalism. In the country, 53 independent systems are in effect, including those of 50 states, federal, Columbia district and Puerto Rico. This circumstance has caused such a specific feature of the American criminal legal system as legal dualism, meaning that in the territory of each state, the law of this state is in effect, while under certain conditions federal law is applied.

The Model Criminal Code of the USA adopted on May 4, 1962, contains description of various fraudulent actions in the sections "Theft and related encroachments" and "Forgery of documents and deceitful methods."

For example, in Article 223.3 of the Model Criminal Code of the USA, theft through deception is envisaged whereby the perpetrator obtains someone else's property via deliberate acts. The property is everything having value: real estate, material and immaterial personal property, contractual rights, property under claims and other interests or claims on property, entrance or transportation tickets, captured pets, food and drink, electrical or other energy.

The maximum punishment is also different everywhere. As a rule, for a petty theft, a fine or imprisonment up to one year are provided for. For a grand scale theft, imprisonment up to 10-20 years can be imposed. In determination of theft degree, Criminal Codes of the states often involve different criteria, particularly the subject of the crime, the way it was committed.

As a whole, in the USA there is no distinction of property to public or private. The crime against any property is punishable. The punishment increases if there are 
aggravating circumstances: a special scoring matrix has been developed in the USA to determine the terms of imprisonment. Each crime has its own point. Aggravating circumstances add points, while mitigating circumstances deduct them.

The Criminal Code of the China People Republic of March 14, 1997, specifies fraud as a crime against property and a crime against the market economic system. In the first case, the Chinese legislator determines liability for fraud with public, private values of significant cost, which is punished by imprisonment for up to 3 years, arrest or surveillance. As an additional or independent punishment, fine is applied. When the amount is sufficient or in other aggravating circumstances, a punishment by imprisonment for a term from 3 to 10 years or lifelong imprisonment are possible.

It should be noted that the regulatory sphere of criminal law in China, i.e., the range of crimes, depends not on subjective will of the legislator, but on a multitude of objective factors. The most important of them is the objective necessity of the Chinese society for struggle with criminality, which is largely influenced, in its rate and structure, by rapid temps of development of the country's economy and reforms in different areas. The socially dangerous acts of new type emerge, while some acts become even more dangerous, which require application of criminal law to struggle against them. The criminal legislation of China, however, is considered too clumsy to timely react to the current changes (Dunmei et al., 2018)

To generalize the above, it might be noted that fraud is extremely widely interpreted in the foreign legislations. In the majority of cases this act can be committed almost in every profitable sphere. As a rule, basic way of fraud is deception specified by not only intellectual effect, but also by making other tricks, resulting from that the perpetrator takes a material profit for itself or for other person.

Therewith, fraud can reveal itself in the commission of actions that create false ideas for the other party of the actual state of affairs, including the deception itself (for example, England, USA). In the criminal codes of many foreign states (like also in the domestic criminal law), circumstances are provided for aggravating the liability (substantial damage, official position etc.). Moreover, breach of trust is specified as an independent crime. Therewith, such an act supposes that the person uses the trust given to it due to its post.

It is also possible to affirm that in the criminal legislation of many foreign states, the multiplicity of legislative fixing of the provisions on economic fraud is displayed. Nevertheless, absence of special provisions on liability for residential real estate fraud shall be noted in almost all countries. As we believe, this state of things doesn't entirely respond to the spirit of time, when real estate fraud is dynamically developing. It is indicated by the statistics of this type of crimes in many countries and by emergence of new fraudulent schedules intended to obtain real estate or rights thereon. 


\section{National Criminal Law Provisions Concerning Issues of Liability for Special Types of Economic Fraud}

In Russia, nearly 2 millions of crimes are registered annually. According to official data of the Ministry of Internal Affairs of the Russian Federation, in 20192024.3 thousand crimes were registered, which is $1.6 \%$ more than over the same period of 2018. More than the half of them (53.5\%) constitute encroachments of property relations, where the most of stealing fall to the share of thefts (774.2 thousand crimes) and fraud (257.2 thousand crimes). With this given, significant difference is detected in increasing the number of frauds as compared to the thefts. For example, in 2019, thefts were committed $2.3 \%$ more than over the same period of 2018 , while frauds were committed $19.6 \%$ more than over the same period of the same 2018 .

The analyzed crime rate indicators for January-July of 2020 point to the fact that the number of thefts committed during that period of time in the territory of the Russian Federation amounts to 353.8 thousand (this indicator is $2.9 \%$ less than over the same period last year), while for frauds it is 158.1 thousand, which is $28.7 \%$ more than over the same period of 2019. These data are represented in the form of a diagram in Figure 1 , from which an increase in the dynamics of fraud against the background of reduction in theft is evident, while the decisive figures for the decrease and increase fall precisely in April-June 2020.

Figure 1. Crime rate indicators for January-July 2019 and 2020.

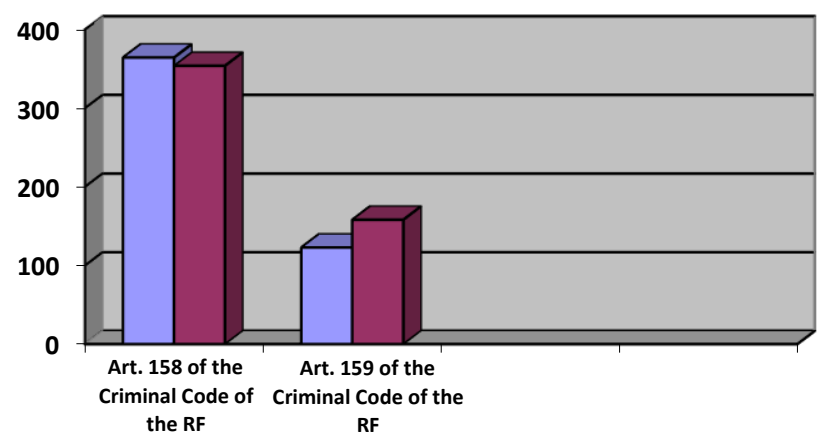

Source: Own study.

Such ambiguous statistics of crimes against property gets its explanation in the fact that during the past three months, starting from March 30, measures have been taken in the Russian Federation to ensure sanitary and epidemiological well-being of the population related to the spread of the new coronavirus infection (COVID-19). The holidays declared in the country have in a certain way modified the nature of crimes against property committed during this period, which is quite explainable, since some specific types of economic fraud (for example, fraud using electronic means of payment in receiving payments or using computer information) are much easier to commit without leaving home than theft, plunder or robbery. 
Despite the legislator's position concerning division of fraud into types, the types of fraud are not distinguished in the official statistics. Fraud in its various ways of manifestation is studied in the framework of common criminal lucrative criminality, based on various forms of direct illegal seizure of someone else's property (Sukhodolov et al., 2018). As a whole, overall growth of fraudulent encroachments is accompanied by their qualitative changes. In the judicial practice of recent years, it is expressed that, along with the classical methods of deception, criminals use new methods with no analogues in the past. Widespread introduction of the achievements of scientific and technical progress in the domain of informatization has significantly influenced a number of crimes with causing them to modify. In addition to the use of information technologies, deception and breach of trust can be based on the knowledge-intensive strategies of latent psychological influence.

Nowadays, economic payment card fraud (carding), dating service fraud, maternity fraud, and home work fraud are becoming widespread. The fraud through mobile communications is becoming more and more sophisticated, including mobile fraud and Internet fraud.

During the last decade, the Russian criminal legislation on fraud has passed a rather difficult and controversial path aimed at its improvement. To grasp the general logic of the modifications introduced into the criminal law, we will attempt to trace the evolution of the criminal law provisions on fraud.

The Federal Law No. 207-FL of November 29, 2012 "On Amendments and Additions to the Criminal Code of the Russian Federation and Certain Legislative Acts of the Russian Federation" has introduced 6 new elements of crime that criminalize fraud: Art. 159.1 of the Criminal Code of the Russian Federation "Credit fraud"; Art. 159.2 of the Criminal Code of the Russian Federation "Fraud in receiving payments"; Art. 159.3 of the Criminal Code of the Russian Federation "Fraud using payment cards" (Federal Law No. 111-FL of 23.04.2018, the title of this article was changed to "Fraud using electronic means of payment"); Art. 159.4 of the Criminal Code of the Russian Federation "Fraud in the sphere of business activity"; Art. 159.5 of the Criminal Code of the Russian Federation "Insurance fraud"; Art. 159.6 of the Criminal Code of the Russian Federation "Fraud in the domain of computer information."

Such a "dispersion" of types of fraudulent actions having received legislative confirmation in 2012, has undoubtedly served as a serious obstacle in the implementation of criminal liability for their commission. While defining the range of necessary changes to the criminal law, the legislator specified, first of all, the most widespread methods of fraud, and thus delimited responsibility for their commission. What, after all, was the need to introduce new elements of crime for fraud caused by? What was the insufficiency of application of Art. 159 of the Criminal Code of the Russian Federation concerning any fraudulent action aimed at taking possession of someone else's property? Let us formulate some suggestions. 
First of all, fraud is interpreted as theft of someone else's property by deception or breach of trust. Upon the allocation of new methods of fraud in separate elements of crime, the classic element of this crime, provided for by Art. 159 of the Criminal Code of the Russian Federation, has not lost its relevance and, regardless of the method of commission, has not lost its specific and generic characteristics. It were only the sanctions that suffered modification, which provide for the type and amount of punishment for certain types of fraud. Out of the analysis of the above mentioned articles, it could be concluded that while introducing special elements of crime for fraud, the legislator primarily pursued the goal of mitigating liability for committing a number of deliberate crimes of lucrative orientation. Such circumstance has led to modification in many sentences, since the Criminal law in this case was retroactive.

The first to come under the wave of criticism was Art. 159.4 "Fraud in the sphere of business activity" In its original form, disposition of this article provided for criminal liability for fraud accompanied by deliberate failure to fulfill contractual business obligations. The first two parts of Art. 159.4 of the Criminal Code of the Russian Federation were related to crimes of little gravity, with the maximum punishment under Art. 3 being imprisonment for up to 5 years, while for the qualification of criminal acts under this article it was necessary to cause property damage in the amount of more than 6 million rubles. While comparing this article with Art. 159 of the Criminal Code of the Russian Federation, which provides for the liability for "simple" fraud, its privileged nature became evident. The main criterion distinguishing the new element of crime from "simple" fraud became the form of expression of the objective side clearly defined by the legislator, that is the method of committing a crime in the form of deliberate failure to fulfill contractual obligations.

These novelties had a number of significant flaws, the main of which being the ambiguity of the concept of "the sphere of business activity". At that time, a blanket interpretation of the concept of "business" with the borrowing of terminology from civil legislation was considered a reasonable solution to this problem. As a matter of practice, it found expression in the fact that all types of fraud committed by participants in business activity were automatically qualified under Art. 159.4 of the Criminal Code of the Russian Federation.

The reason for this was largely the position of the Supreme Court of the Russian Federation, set out in its Decree of 19.12.2013 No. 41 'On the practice of the courts' application of legislation on preventive measures in the form of detention, house arrest and bail", which indicated the necessity to qualify crimes under Art. 159.4 of the Criminal Code of the Russian Federation, if they were committed by persons engaged in business activity and were directly related to the mentioned activity.

This approach was expectedly misunderstood by law enforcement officers. A paradoxical situation emerged when a person having committed a crime that entailed socially dangerous consequences in the form of causing material damage to the victim received significant privileges only due to his socio-economic status as a participant 
in business activity. As a result, the Decree of the Constitutional Court of the Russian Federation of December 11, 2014 No. 32-P was adopted, which recognized the provisions of Art. 159.4 of the Criminal Code of the Russian Federation not corresponding to the Constitution of the Russian Federation. The main motive for exclusion of the article from the Criminal Code of the Russian Federation was the disproportionality of the sanction for social danger of crime established by it.

In 2018, the disposition of Art. 159.3 of the Criminal Code of the Russian Federation has suffered certain changes: the title of the article was subject to certain modifications by Federal Law of April 23, 2018 No. 111-FZ, thus the criminal liability under this article currently arises for committing fraudulent actions using electronic means of payment. Sanction of Part. 1 of Art. 159.3 of the Criminal Code of the Russian Federation has also suffered changes: the same Federal Law of 23.04.2018 No. 111FL has modified the punishment to a more severe one: in Part 1 of Art. 159.3 of the Criminal Code of the Russian Federation the words "arrest for up to four months" were replaced by the words "imprisonment for up to three years".

However, one can observe now a certain bias in the approach to punishment for acts falling under the indications of Part. 1 of Art. 159.3 of the Criminal Code of the Russian Federation and Part. 3 of Art. 158 of the Criminal Code of the Russian Federation (meaning the point " $\Gamma$ " of this Part, that is theft committed from a bank account, as well as that related to electronic funds). These two elements of crime could be called intercomplementary to each other, however, the point " $\Gamma$ " of Part. 3 of Art. 158 of the Criminal Code of the Russian Federation provides for punishment in the form of imprisonment for up to six years (the crime belongs to the category of grave crimes), and in the sanction of Part. 1 of Art. 159.3 of the Criminal Code of the Russian Federation, imprisonment cannot exceed three years, which makes it possible to classify this crime as that of a minor gravity. Thus, it comes to a situation that the theft committed from a bank account, as well as that related to electronic funds, regardless of the amount of damage caused to the owner, will always be considered a grave crime, while Art. 159.3 of the Criminal Code of the Russian Federation differentiates criminal punishment in the form of imprisonment depending on the amount of damage caused.

It is quite logical to suggest that in practice this will entail various approaches to the qualification of criminal acts which are contiguous by their content. As an escape from this situation, in our opinion, the exclusion of point " $\Gamma$ " from Part. 3 of Art. 158 of the Criminal Code of the Russian Federation as a provision creating the possibility of a double interpretation of the criminal law could be considered. Instead of this, we find it possible to introduce a separate provision on the theft of funds from a bank account, as well as that related to electronic funds, providing for qualified elements of crime there, depending on the amount stolen and thus delineating the punishment by analogy with Art. 159.3 of the Criminal Code of the Russian Federation. 
As mentioned above, Part. 2, 3 and 4 of Art. 159.3 of the Criminal Code of the Russian Federation differentiate punishment depending on the stolen amount. In July 2016, the Federal Law No. 325-FL of 03.07.2016 "On Amendments to the Criminal Code of the Russian Federation and the Criminal Procedure Code of the Russian Federation" has suffered change in Part. 2 and Part. 3 of this article, concerning also hardening of punishment. Thus, in the Sec. 2 of Part. 2, the words "imprisonment for up to four years" should be replaced by the words "imprisonment for up to five years", and in Sec. 2 of Part. 3, the words "imprisonment for up to five years" should be replaced by the words "imprisonment for up to six years". In this regard, it can be claimed with full confidence that the legislator seeks to trace the extent of fraud in the mentioned area, while fixing it legally by indicating the methods and forms, as well as adjusting the amount of punishment for this act in accordance with the principle of justice.

It is also important to note that the Federal Law of 23.04.2018 No. 111-FL has revised the amount of damage, making it possible to recognize fraud under Art. 159.3 and 159.6 of the Criminal Code of the Russian Federation in large and highly large scales, as the note to Art. 158 of the Criminal Code of the Russian Federation has been amended. Thus, in Art. 159.3 and Art. 159.6 of the Criminal Code of the Russian Federation a theft exceeding 250 thousand rubles is currently considered as a large scale crime, while 1 million rubles is a highly large scale crime (earlier in the above mentioned Articles, the amount of more than 1.5 million rubles was recognized as a large scale, and more than 6 million rubles - as a highly large scale). In this connection, it becomes relevant to speak of increase in the frequency of application of this legislative provision, since the lower threshold for recognizing acts as criminal and committed with qualifying indications (on a large and highly large scale) looks quite realistic and quite widespread.

It is notable that in Part. 3 and Part. 4 of Art. 159.3, 159.5 and 159.6 of the Criminal Code of the Russian Federation, the legislator provided for the possibility of imposing a fine as an additional type of punishment to that in the form of imprisonment, for they provide for causing damage on a large or highly large scale. However, in Part. 2 of the same Articles, which provide for liability for special types of economic fraud with significant damage to a citizen, any additional penalty in the form of a fine is absent. Thus, implement the goals and objectives of the criminal prosecution completely, and not partially, it seems reasonable to provide for the possibility of imposing a fine as an additional punishment to imprisonment in Part. 2 Art. 159.3, Part. 2 Art. 159.5 and Part. 2 Art. 159.6 of the Criminal Code of the Russian Federation. Such an approach will promote implementation of the principle of justice and will have a preventive basis.

\section{Assessment of the Risks Related to Various Types of Economic Fraud}

In an effort to adapt criminal law to modern realities, the legislator often overlooks the fact that lawmaking is an important regulator of the considered relations, but it is not the only one (Petrasheva et al., 2017). Conducting the assessments of the risks 
related to economic fraud contributes to systematic efforts to clarification of where and which way may an economic fraud problem emerge, and also helps to create appropriate controls to minimize the risks related thereto. Such assessments include specification of respective risk factors related to economic fraud; identifying and prioritizing potential fraudulent schemes with accounting the risks; determining the level of acceptable risks related to economic fraud; systematization of data on available mechanisms for counteracting potential fraudulent schemes and identification of gaps in this area; and also testing the effectiveness of control mechanisms designed to prevent and detect economic fraud.

Assessments of the risks related to economic fraud, coupled with a systematic review of incoming information and experience gained from past and present cases of fraud, are of key importance to estimate vulnerability of various domains of public relations.

Let us try to characterize and calculate the degree of risk of economic fraud using electronic means of payment as the most actively spreading criminal phenomenon in recent years. The risks related to economic fraud using electronic means of payment could be quantified, for they are associated with unauthorized transactions on a bank customer's account using a bank card as a tool for access to it. This fraud is aimed at information asset (customer account), the value whereof has a monetary value. Therefore, for a single card, the risk will be:

$$
S F R=P_{\text {fraud }} \times S_{\text {am }},
$$

where $P_{\text {fraudis }}$ probability of a fraudulent card transaction,

$S_{a m}$ is the amount of funds available on the account (under a debit or credit agreement between the bank and the client).

To obtain the risk value according to the given formula, it is necessary to calculate the probability of fraudulent transactions, since the amount of funds available on the client's bank account is known.

A fraudulent transaction can be characterized as a transaction using a bank card or its details not initiated or confirmed by its holder. A fraudulent transaction can be made once the following conditions are met simultaneously:

- compromise of card data, where the data of the magnetic stripe of the card and (or) PIN-code, its details and (or) password for secure payments on the Internet 3D Secure have been compromised;

- using card data, which means making a card that can be accepted for payment at a merchant or ATM for fraudulent card fraud;

- initiation of a transaction, where a malefactor initiates a transaction using a fake card or compromised details; 
- completion of a transaction, which means authorization by the issuer for transactions carried out in real time (online), and performing an operation on the card account for offline transactions.

Hence the probability of a fraudulent operation $P_{\text {fraud }}$, taking into account the conditional probability formula and the formula we have provided above, can be determined as follows:

$$
P_{\text {fraud }}=P_{(\text {cpr })} \times P_{(\text {use/cpr })} \times P_{(\text {non } / \text { cpr } \times \text { use })} \times\left(1-P_{(d e t)}\right),
$$

Where: $\mathrm{P}$ (cpr) is the probability of compromising card data required for a fraudulent transaction,

$P$ (use $\mid$ cpr) is the probability of using compromised data (for example, to make a fake card),

$P$ (non $\mid$ cpr $\cdot$ use $)$ - is the probability of performing an unauthorized transaction (success of an attempt to perform);

$P($ det $)$ is the probability of detection of an unauthorized transaction by the issuer (Voronin, 2016).

As a whole, it should be noted that conducting assessments of the risks related to various types of economic fraud gives a ground for development of strategies to counter these criminal acts that are relevant to the current conditions.

\section{Conclusion}

The provisions on criminal responsibility for economic fraud are constantly causing debate among scientists and practitioners and are subject to amendments over the years based on objective reasons. The study of the comments available in the legal literature regarding the imperfection of both the general and the special provisions on fraud (Art. 159, 159.1-159.3, 159.5, 159.6 of the Criminal Code of the Russian Federation), allows us to conclude over the necessity of their reforming. In most cases, it is the imperfection of special rules on fraud that is criticized, which is in the inconsistency of the general and special provisions, as well as in the imperfection of the content of indications of economic fraud committed in various domains of public relations, primarily due to that these circumstances negatively affect the law enforcement process (Seregina and Lavrenshina, 2018).

As recommendations directed to improving the national legislation on criminal liability for fraud, the following can be emphasized:

- it is necessary to exclude item " $\Gamma$ " from Part 3 of Art. 158 of the Criminal Code of the Russian Federation as a provision creating the possibility of a double interpretation of the criminal law;

- to introduce a separate provision on the theft of funds from a bank account, as well as that related to electronic funds, providing for qualified elements of crime there, 
depending on the amount stolen and thus delineating the punishment by analogy with Art. 159.3 of the Criminal Code of the Russian Federation.

- in Part. 2 Art. 159.3, Part. 2 Art. 159.5 and Part. 2 of Art. 159.6 of the Criminal Code of the Russian Federation, it is reasonable to provide for the possibility of imposing a fine as an additional punishment to imprisonment.

In addition, assessment of risks related to various types of economic fraud is key to detecting and preventing economic crime.

\section{References:}

Bissengal, L., Dzhansarayeva, R.Y., Lopashenko, N.A., Sharipova, A.B., Mukhamadiyeva, G.N. 2017. Some Problems of Determination of «Economic Crime» Concept. Journal of Advanced Research in Law and Economics, S1 (8), 2094-2102.

Chetyrin, N.A. 2009. Responsibility for fraud in the criminal law of foreign countries. Bulletin of TSU, 6 (74), 413-416.

CO. 2019. The state of criminality in the Russian Federation in January-December 2018. Available online: https://xn--b1aew.xn--p1ai/reports/item/16053092/

CO. 2020a. The state of criminality in the Russian Federation in January-December 2019. Available online: https://xn--b1aew.xn--p1ai/folder/101762

CO. 2020b. The state of criminality in the Russian Federation in January-June 2020. Available online: https://xn--b1aew.xn--p1ai/reports/item/20597695/

Dunmei, P., Binzi, Z., Vasiljev, I.A. 2019. Problems of Criminalizing Actions in Chinese Criminal Law. Russian Journal of Criminology, 1(13), 142-151.

Nikiforov, A.S. 1969. Model Criminal Code (USA). 1969 Official Project of the Institute of American Law $=$ Model penal code: The American Law Institute Proposed Official Draft. Moscow, Progress Publishing house, 303.

Petrasheva, N.V., Ulezko, S.I., Yakovlev, A.V., Klochkova, A.L. 2017. Economic crime and problem of complicity understanding. European Research Studies Journal, 1(20,) 208214.

Seregina, E.V., Lavreshina, A.Yu. 2018. Impact of changes in the criminal legislation on the dynamics of fraud. Criminal law: current state and development prospects, proceedings of the II International Scientific and Practical Conference dedicated to the day of the adoption of the Criminal Code of the Russian Federation, 242-246.

Shabalin, L.I. 2014. Fraud in the criminal law of Russia, England, Germany, Spain, France and Japan: comparative legal analysis. Electronic supplement to the "Russian legal journal", 1, 34-40.

Sukhodolov, A.P., Novikova, N.G, Kubasova, T.I., Khomkalov, G.V., Lavygina, I.V. 2018. Factors determining fraud in equity construction. Russian Journal of Criminology, 1 (12), 92-100.

Voronin, A. 2016. Payment fraud. Business encyclopedia, Center for Research of Payment Systems and Accounts. Intellectual Literature. 